Vol. 17 (2008): 18-30.

\title{
Management of investment processes on Finnish farms
}

\author{
Timo Mattila \\ MTT Agrifood Research Finland, Economic Research, present address: Valtra Inc. FI-44200 Suolahti, Finland \\ email: timo.mattila@valtra.com \\ Marja Manninen \\ MTT Agrifood Research Finland, Economic Research, present address: ProAgria Farma, Artturinkatu 2, \\ FI-20200 Turku, Finland \\ Pasi Rikkonen \\ MTT Agrifood Research Finland, Economic Research, Luutnantintie 13, FI-00410 Helsinki, Finland \\ Hanna-Riitta Kymäläinen \\ University of Helsinki, Department of Agrotechnology, PO Box 28, FI-00014 University of Helsinki, Finland
}

Structural change in agriculture means a continuous need for investing in farm production. It is essential for the sustainable operations and the economy of the farm that such investments are successful. In this research, different stages of the investment process of farms were studied as well as the use of information and the success perceived during the investment process. The study was carried out with mail surveys and telephone interviews on the Finnish Farm Accountancy Data Network (FADN) farms. The most challenging investments were in animal husbandry buildings and, as to these investments, the comparison of alternatives was the most challenging stage. For most investments, the planning phase was considered more challenging than the implementation. Before making the decision, farmers acquired information from many sources, of which the opinion of the main customer and the experiences of fellow farmers were the most valued. Some of the products considered were so new on the market that it was not easy to get adequate information and, furthermore, the information given by suppliers was not always accurate. Decision-making was supported by calculations, but qualitative factors had a dominating role. Large basic decisions were made relatively quickly, while details needed a longer time to process. In general, farm managers were satisfied with their investments. Improvements in work quality and quantity were especially mentioned and generally qualitative factors were the ones first in mind when evaluating the successfulness of the investment.

Key-words: Investment process, decision-making, buying behaviour, farm management 
Vol. 17 (2008): 18-30.

\section{Introduction}

Over the past ten years during which Finland has been a member of the European Union (EU), the level of agricultural production has been maintained despite a rapid decrease in the number of farms and employees in the sector. The growth of profitability of farms has stalled or even reached negative values in the same period. However, farming enterprises with continuous growth have managed to improve their income. In 2004, the Finnish farming sector spent $€ 582$ million on machinery and $€ 287$ million on buildings, equalling together one third of all farming costs. These costs, including depreciation, repair and maintenance, have stayed roughly at the same level (Niemi and Ahlstedt 2006).

Enterprises look for increasing profits, and investments in production are made to guarantee future profitability. In addition, farmers as entrepreneurs have many quantitative and qualitative goals other than purely economic ones, such as good living and independence (Sonkkila 2002). A high level of human work in unpleasant conditions often leads to investing in new technology (e.g. Hogeveen et al. 2004). In the study reported by Hadley et al. (2002), the need to improve profitability and quality of life was the most important reasons for investing in expanding production on Wisconsin and Michigan dairy farms. Improving life quality may include, e.g. improvements in the organisation of work and more leisure time. An agricultural enterprise is typically a working place for a family, being their home at the same time, and many farmers plan to maintain the farm so that it can be in an operating condition over several generations (Doyle et al. 2000).

The farming sector commonly shares the opinion that production on a farm has to have continuous development or be disbanded (Haring 2003, Ondersteijn et al. 2006). The need for investment is often caused by lost or missing competitiveness or by the increasing demand from a large customer or from the market (Palojärvi 2000). The investment process starts when a new possibility appears or when a gap between wanted and achieved results emerges. The need to avoid accidental situations like machine breakdowns during peak season raises the question of replacing machinery. Jacobsen (1997) found out that the fear of breakdowns seemed to be the biggest reason to buy new machinery. The development of technology and the need for additional capacity were important reasons as well, but less important than forecasted high costs caused by breakdowns and work interruptions.

Development by investing is often challenging. According to Palojärvi (2000), an investment is usually an extraordinary activity for a small enterprise. He found little formal long-time planning concerning investments in Finnish small- and medium-sized enterprises (SMEs) in machine building and marketing businesses. Managers running these enterprises often had a low level of education. Danish farms invest a lot in machinery without proper planning, resulting a $25-50 \%$ higher yearly investment than estimated in advance (Jacobsen 1997). In the study by Wilson et al. (2001), farmers who had further education or who actively sought out information were technically more effective than farmers with less education.

Many enterprises and entrepreneurs include seeking future business and investment possibilities in their routine operations. However, in the study by Palojärvi (2000), SMEs did not actively look for investment ideas, but they often received ideas from customers. Development taking place in neighbourhood farms can also create pressure to invest (Sipiläinen 1997, Micheels et al. 2004). Diversification is often a reason to invest. At least on Finnish farms, diversification is in most cases based on production and resources already available on the farm (Rantamäki-Lahtinen 2004). Primary goals were a more effective use of farm machinery and buildings as well as better pricing for products.

Making an investment in machinery or other means of production can follow a similar process as found in process studies concerning institutional buying. One of the most well-known buying models is the process model reported by Robinson et al. (1967), referred to and completed by Johnston and Lewin (1996). In this model, the buying process is divided into eight stages: 


\section{AGRICULTURAL AND FOOD SCIENCE}

Mattila, T. et al. Investment processes on farms

1. Need recognition;

2. Definition of the characteristics and quantity of item needed;

3. Development of specifications to guide the procurement;

4. Search for and qualification of potential sources;

5. Acquisition and analysis of proposals;

6. Evaluation of proposals and selection (choice) of (product and) suppliers;

7. Selection of an order routine;

8. Performance feedback and evaluation.

Verville and Halingten (2003) used a six-stage process in which they illustrated a major investment in software made by an enterprise. They found out that a previous stage could continue on, even though a following stage had already begun, with the result that there were several active stages at the same time. Because a farm is generally a producing enterprise, its buying process can be described with a general model (Anderson 1987). After studying decision-making on a farm concerning large unique decisions which can be or include substantial investments, Ohlmer et al. (1998) launched a model in which the decision process was divided into four stages: problem detection, problem definition, analysis and choice and implementation. Major extension in their work was to divide each of the stages in four sub-processes: 1) searching and paying attention, 2) planning and forecasting consequences, 3) evaluating and choosing, and 4) bearing responsibility.

Despite the literature available concerning decision-making in general, industrial buying processes and some published works concerning machinery purchases, little detailed information concerning the investment process of farmers is available. The general aim of this study was

1. to deepen the knowledge of the actions of farmers during the investment process,

2. to define those problems related to investments,

3. to clarify the role of information in the investment process,

4. to investigate how farmers perceive the successfulness of their investment.
The specific focuses were on 1) finding out how farmers see the investment process and 2) how their challenges vary in different investment types. Farm income and profitability are influenced by many factors beyond the scope of this study. It was therefore not possible to measure the actual efficiency improvement resulted by the investment.

\section{Material and methods}

Experimental research was based on two data collection phases, the first consisting of a mail survey and the collection of basic data, and the second consisting of a limited number of interviews. In the first part in February 2005, a questionnaire was sent to those farmers who belong to the Farm Accountancy Data Network (FADN) system in Finland. The survey was based on a sample of nearly 1,000 farms. The database is maintained by MTT Agrifood Research, Economic Research. FADN farms are typical family farms with an average field size, in 2002, of 44 ha (Puurunen 2005). In the second part, researchers conducted an in-depth telephone interview of nine farms. The interviews were carried out in October 2005. The respondents and interviewees were presumed to be farm managers or fully engaged in farm management.

In the mail survey questionnaire, the respondents were asked first and foremost to name the most and the second most demanding investment completed during the years 1995-2004. Secondly, the investment process was divided in the questionnaire into two phases, planning and implementing, including together nine different tasks. The farmers were asked to estimate how demanding they felt different tasks were in planning and implementing the investment. Estimation was made by choosing a number on a scale from one (easy) to five (very challenging or demanding). 420 farmers $(53 \%)$ answered the enquiry and 366 answers (46\%) were complete and could be used in the analyses. 
Enquiry data was combined with the farm FADN identification number for the years 2000 and 2003. FADN data includes, e.g. information about farm structure, production of each farm, financial results, production costs, profits, and subsidies. Also farm assets and restricted equity were calculated. The FADN data is collected according to international requirements and the most essential part of the gathered data are comprised of the tax bookkeeping notes. The compatibility of the FADN data with the subsidy register of the Finnish Ministry of Agriculture and Forestry has been checked (Puurunen 2005). In our study, the mail survey part was carried out with farms within the FADN system. As part of the FADN system development, there are studies which have evaluated the non-responsiveness in the years 1998 to 2002 (Manninen 2004). The only minor differences were found in the variable of cultivated field area, but the differences between the groups of respondents and non-respondents were not statistically significant. Although there are slight changes in yearly participative farms in the FADN system, we did not repeat the nonresponse analysis in this case.

Interviews were based on a specific, semistructured questionnaire. Interviewed farms were selected from the respondents of the mail survey who had claimed to have had a challenging investment process (the investment process demand rate to be 4 or over, as an average on all questions). They were informed in advance about the linkage between the previous mail survey and interview, but they did not have access to the themes either before or during the interview. The investment process schemes were followed during the interviews so that the discussion started by finding out the farm strategy and the development and actions prior, during and after the investment in question. The goal for the interviewee was to ascertain the problems and challenges. In order to expand fully these themes and to double-check the answers, some confirming questions were added after the end of the process discussion. Interviews were recorded and coded for analysis. In the interview, the impact of the researcher on the interviewee was kept as discreet as possible.

\section{Statistical analysis of enquiry data and qualitative analysis of interviews}

Statistical analyses for the data obtained from the FADN data and the mail questionnaires were performed using the SAS EG 3.0 programme. All the data were divided into five groups according to the most demanding investment. The groups were: 1) domestic animal production buildings, 2) other production buildings, 3) land and drainage (including buying additional land or transfer of a farm to a descendant), 4) machinery investment, and 5) other investment. The last group included e.g. investments in residential buildings and tourism. This group consisted of seven cases and it was omitted from the final data analysis because of the small number of cases with a lot of inequality. Differences between the first four groups in the investment processes and in enterprise characteristics were studied by variance analysis. The normality of distribution was tested graphically by quantile-quantile plots and homogeneity of variances was determined with the Levene test. Welch's analysis of variance was used in cases when the assumption of homogeneity of variance was rejected. Within the groups, the correlations between challenge rates and farm size and profitability were studied.

The material collected through interviews was analysed only with qualitative methods. At first, the data was categorized by identification of themes and types. The following were selected as essential central themes as: 1) challenge, e.g. descriptions of difficulties in the investment process and generally how demanding the stage in question was, 2) acquiring, processing and the use of information, and 3 ) feedback and control of the investment. Statements which belonged to one or several of these themes were collected from the interviews. With these statements, it was possible to find answers to research questions from the viewpoint of one farm.

The second step in the analysis of the interview data was the identification of types. This meant that similarities were searched for and identified from different interviews. By means of these similarities, it was possible to describe how the invest- 


\section{AGRICULTURAL AND FOOD SCIENCE}

\section{Mattila, T. et al. Investment processes on farms}

ment process had been performed on the farms studied. The results of the qualitative study cannot be generalised for the entire population, but they can be discussed and compared with the results of the mail survey and with the literature concerning the subject. In addition, based on available literature, it was possible to find out how the previous investment and buying process models performed in this context.

\section{Results}

According to the mail survey data, the group of farms which stated investment in animal husbandry production buildings to be the most important, had as well the largest average farm size, measured by European size units (ESU), turnover and growth of turnover (Table 1). These farms had young managers and they gave the highest rates concern- ing the challenge in investment among the farm groups. Most tasks were more demanding than in other types of investment. The planning phase was considered to be more demanding than the construction phase of the building. 'Comparison between the different options' was considered as the most demanding and 'specifying the needs' as least demanding in the planning phase (Table 2).

Investment in other buildings was made on relatively small farms (Table 1) and all tasks except financial planning, control and management were considered less demanding than in animal building investments (Table 2). The planning phase was considered to be on the same level as the implementation of the investment, and 'Applying investment supports' was considered as the most demanding task in the planning phase (Table 2).

When the most important investment concerned additional land or subsoil drainage, the investment process was in most tasks statistically significantly less demanding than investment in animal build-

Table 1. The grouping of farms which responded in the mail enquiry. Except for 'group size', all numbers are means. The mean ratings marked with a different letter $(\mathrm{a}, \mathrm{b}, \mathrm{c}, \mathrm{d})$ within the rows are statistically significantly different from each other at $p<0.05$ level. Demand rates were reported on a scale from 1 (easy) to 5 (very challenging).

\begin{tabular}{|c|c|c|c|c|c|}
\hline \multirow[b]{2}{*}{ Parameter } & \multicolumn{5}{|c|}{$\begin{array}{l}\text { The object of the most important investment on respondent farms during } \\
\qquad 2000-2005\end{array}$} \\
\hline & $\begin{array}{l}\text { Animal production } \\
\text { buildings }\end{array}$ & $\begin{array}{l}\text { Other } \\
\text { buildings }\end{array}$ & $\begin{array}{l}\text { Land, } \\
\text { drainage }\end{array}$ & Machinery & All \\
\hline $\begin{array}{l}\text { Group size } \\
\text { Demand rate according to mail survey }\end{array}$ & 106 & 90 & 71 & 97 & 366 \\
\hline Average over planning phase & $3.1^{\mathrm{a}}$ & $2.5^{b}$ & $2.3^{b}$ & $2.3^{\mathrm{b}}$ & 2.6 \\
\hline $\begin{array}{l}\text { Average over implementing phase } \\
\text { The age of the respondent at the time of }\end{array}$ & $2.7^{\mathrm{a}}$ & $2.3^{a b}$ & $2.1^{b c}$ & $1.9^{\mathrm{c}}$ & 2.3 \\
\hline investment (year) & $37.8^{a b}$ & $43.6^{\mathrm{abd}}$ & $37.4^{\mathrm{ab}}$ & $43.6^{\mathrm{b}}$ & 41 \\
\hline Farm size $2003\left(\mathrm{ESU}^{1}\right)$ & $77^{\mathrm{a}}$ & $43^{b}$ & $45^{b}$ & $34^{b}$ & 52 \\
\hline $\begin{array}{l}\text { Farm turnover for year } 2003(€) \\
\text { Annual growth of turnover } 2000-03\end{array}$ & $202,600^{\mathrm{a}}$ & $105,300^{b}$ & $113,400^{\mathrm{b}}$ & $78,800^{b}$ & 128,000 \\
\hline$(\%)$ & $10.0^{\mathrm{ac}}$ & $7.7^{\mathrm{cd}}$ & $10.4^{\text {abcd }}$ & $3.6^{\mathrm{bc}}$ & 8.6 \\
\hline $\begin{array}{l}\text { Entrepreneurial income for } 2003(€) \\
\text { Annual growth of entrepreneurial in- }\end{array}$ & $41,800^{c}$ & $25,000^{\mathrm{bcd}}$ & 32,800 abc & 18,700 bd & 29,700 \\
\hline $\begin{array}{l}\text { come } 2000-03(\%) \\
\text { Profitability coefficient }{ }^{2}\end{array}$ & $4.2^{\mathrm{a}}$ & $3.5^{\mathrm{a}}$ & $6.7^{\mathrm{a}}$ & $-3.1^{a}$ & 3.0 \\
\hline 2000 & 0.86 & 0.76 & 0.96 & 0.79 & 0.84 \\
\hline 2003 & 0.68 & 0.55 & 0.69 & 0.55 & 0.62 \\
\hline
\end{tabular}

${ }^{1}$ ESU: European size unit, expressing the economic size of a farm

${ }^{2}$ Profitability coefficient: family farm income per sum of the wage and interest claims of farm family 
Vol. 17 (2008): 18-30.

Table 2. Average demand rates on different tasks in each investment group as means and standard errors (in parentheses). The mean demand ratings marked with a different letter $(\mathrm{a}, \mathrm{b}, \mathrm{c})$ within the rows are statistically significantly different from each other at $p<0.05$ level. Demand rates were reported on a scale from 1 (easy) to 5 (very challenging).

\begin{tabular}{lllll}
\hline \multirow{2}{*}{ Task } & \multicolumn{2}{l}{$\begin{array}{l}\text { The averages (and standard errors) of the demand rates in different tasks in dif- } \\
\text { ferent investment groups }\end{array}$} \\
\cline { 2 - 5 } & $\begin{array}{l}\text { Animal produc- } \\
\text { tion buildings }\end{array}$ & Other buildings & Land and Drainage & Machinery \\
\hline Planning phase, average & 3.05 & 2.52 & 2.27 & 2.25 \\
1. Specifying the needs & $2.70(0.14)^{\mathrm{a}}$ & $2.08(0.14)^{\mathrm{b}}$ & $1.84(0.15)^{\mathrm{b}}$ & $2.07(0.13)^{\mathrm{b}}$ \\
2. Acquiring information & $3.08(0.11)^{\mathrm{a}}$ & $2.49(0.13)^{\mathrm{b}}$ & $1.88(0.13)^{\mathrm{c}}$ & $2.28(0.12)^{\mathrm{b}}$ \\
3. Comparison & $3.34(0.11)^{\mathrm{a}}$ & $2.64(0.13)^{\mathrm{b}}$ & $2.07(0.14)^{\mathrm{c}}$ & $2.47(0.12)^{\mathrm{b}}$ \\
4. Economic calculations & $3.18(0.11)^{\mathrm{a}}$ & $2.64(0.12)^{\mathrm{b}}$ & $2.61(0.16)^{\mathrm{b}}$ & $2.41(0.11)^{\mathrm{b}}$ \\
5. Applying investment supports & $3.03(0.12)^{\mathrm{a}}$ & $2.97(0.13)^{\mathrm{a}}$ & $2.62(0.19)^{\mathrm{ab}}$ & $2.34(0.18)^{\mathrm{b}}$ \\
6. Financial planning & $2.94(0.12)^{\mathrm{a}}$ & $2.56(0.12)^{\mathrm{ab}}$ & $2.46(0.15)^{\mathrm{ab}}$ & $2.13(0.10)^{\mathrm{b}}$ \\
7. Decision-making as whole & $3.16(0.12)^{\mathrm{a}}$ & $2.45(0.13)^{\mathrm{b}}$ & $2.27(0.17)^{\mathrm{b}}$ & $2.44(0.12)^{\mathrm{b}}$ \\
Implementing phase, average & 2.73 & 2.29 & 2.09 & 1.91 \\
1. Financial arrangements & $2.55(0.12)^{\mathrm{a}}$ & $1.98(0.12)^{\mathrm{b}}$ & $2.02(0.14)^{\mathrm{b}}$ & $1.81(0.10)^{\mathrm{b}}$ \\
2. Buying arrangements & $2.96(0.11)^{\mathrm{a}}$ & $2.38(0.13)^{\mathrm{b}}$ & $2.00(0.16)^{\mathrm{b}}$ & $1.99(0.14)^{\mathrm{b}}$ \\
3. Deliveries & $2.74(0.10)^{\mathrm{a}}$ & $2.26(0.12)^{\mathrm{b}}$ & $2.05(0.17)^{\mathrm{bc}}$ & $1.76(0.10)^{\mathrm{c}}$ \\
4. Supervision of implementation & $2.84(0.11)^{\mathrm{a}}$ & $2.59(0.13)^{\mathrm{a}}$ & $2.10(0.16)^{\mathrm{b}}$ & $1.86(0.12)^{\mathrm{b}}$ \\
5. Learning to manage & $2.86(0.11)^{\mathrm{a}}$ & $2.66(0.12)^{\mathrm{a}}$ & $2.38(0.17)^{\mathrm{ac}}$ & $2.12(0.13)^{\mathrm{c}}$ \\
6. Learning to operate & $2.50(0.11)^{\mathrm{a}}$ & $1.99(0.12)^{\mathrm{b}}$ & $2.15(0.18)^{\mathrm{ab}}$ & $2.22(0.13)^{\mathrm{ab}}$ \\
\hline
\end{tabular}

ings (Table 2). When planning, especially specifying the need for and collecting information were considered less demanding than planning the financial aspects and applying for the subsidies for the project.

Investment in machinery was considered less demanding than investment in animal buildings in both phases and all tasks, but not concerning learning how to operate. No statistically significant differences were observed between the demand of the tasks either in their planning or in their implementation (Table 2). On average, planning was more demanding than implementing only where 'learning' tasks exceeded, on average, a 2 point rating.

According to the interviews, investments were aimed at developing one of the farm's present lines of production (Table 3). In the background, there usually was also a clear and often urgent need to update worn-out or obsolete buildings or machinery. The farmer's own values and intuition as well as the farmer's own competence were behind the investment, while an actual need was named so as to strengthen production efficiency and capacity. All interviewed farmers had found a clear strategy to follow, which was either (1) maintaining the current production level with improved production process, or (2) expanding the production level. A rejected alternative for both, when mentioned, was (3) the discontinuation of production. The greatest uncertainty felt concerned a future operational environment, and especially as regards political decisions, with statements such as "It was good that we put this up, because it seems you can only trust political decisions for no more than a few weeks". 


\section{Mattila, T. et al. Investment processes on farms}

Table 3. A short description of all farmers interviewed: management, needs and information sources behind the investment. Evaluation of the results.

\begin{tabular}{|c|c|c|c|c|}
\hline \multirow{2}{*}{$\begin{array}{l}\text { Recent main invest- } \\
\text { ment on the farm }\end{array}$} & \multirow{2}{*}{$\begin{array}{l}\text { Decision } \\
\text { makers }^{1} \\
\text { on farm }\end{array}$} & \multicolumn{3}{|c|}{ Needs, information and success } \\
\hline & & $\begin{array}{l}\text { Main needs lead to } \\
\text { the investment }\end{array}$ & $\begin{array}{l}\text { Most important (external) } \\
\text { sources of information }\end{array}$ & $\begin{array}{l}\text { Measuring the success }{ }^{2} \\
\text { of the investment }\end{array}$ \\
\hline $\begin{array}{l}\text { 1. Dairy barn with } \\
\text { automatic milking } \\
\text { system }\end{array}$ & 2 & $\begin{array}{l}\text { technology up- } \\
\text { date and expand } \\
\text { production }\end{array}$ & $\begin{array}{l}\text { experiences learned by oth- } \\
\text { er farmers }\end{array}$ & $\begin{array}{l}\text { possibility to stay in } \\
\text { business, improved } \\
\text { workplace }\end{array}$ \\
\hline 2. Tractor & 1 & $\begin{array}{l}\text { replacement technol- } \\
\text { ogy update }\end{array}$ & suppliers & improved workplace \\
\hline $\begin{array}{l}\text { 3. Grain dryer and } \\
\text { store }\end{array}$ & 1 & expand & $\begin{array}{l}\text { own construction and plan- } \\
\text { ning, suppliers }\end{array}$ & $\begin{array}{l}\text { functionality, } \\
\text { profitability }\end{array}$ \\
\hline 4. Pig fattening barn & $1(2)$ & $\begin{array}{l}\text { technology up- } \\
\text { date and expand } \\
\text { production }\end{array}$ & slaughterhouse, suppliers & $\begin{array}{l}\text { possibility to stay in } \\
\text { business, improved } \\
\text { workplace }\end{array}$ \\
\hline 5. Hog barn & 2 & $\begin{array}{l}\text { technology up- } \\
\text { date and expand } \\
\text { production }\end{array}$ & slaughterhouse, suppliers & $\begin{array}{l}\text { profitability, amount and } \\
\text { quality of work }\end{array}$ \\
\hline $\begin{array}{l}\text { 6. Baler-wrapper } \\
\text { combination }\end{array}$ & 1 & $\begin{array}{l}\text { technology update } \\
\text { for efficiency }\end{array}$ & $\begin{array}{l}\text { experience of other farm- } \\
\text { ers, journals }\end{array}$ & $\begin{array}{l}\text { amount of work, cost } \\
\text { level }(* *)\end{array}$ \\
\hline 7. Poultry barn & $1(2)$ & expand & slaughterhouse, suppliers & profitability \\
\hline $\begin{array}{l}\text { 8. Dairy barn, updat- } \\
\text { ed technology }\end{array}$ & 1 & $\begin{array}{l}\text { technology update } \\
\text { for efficiency }\end{array}$ & $\begin{array}{l}\text { advisory centre and dairy } \\
\text { consultants }\end{array}$ & improved workplace \\
\hline 9. Dairy barn & 2 & $\begin{array}{l}\text { technology up- } \\
\text { date and expand } \\
\text { production }\end{array}$ & $\begin{array}{l}\text { experience of other farm- } \\
\text { ers, journals }\end{array}$ & $\begin{array}{l}\text { amount of work, im- } \\
\text { proved workplace }(* *)\end{array}$ \\
\hline
\end{tabular}

The interviews showed that the basic definition of the type and the major characteristics of the investments have often been made in a relatively straightforward way. If investing in buildings, the basic selection among options took place at an early phase of the investment and usually there were only one or few alternatives which could have been considered suitable. Usually, the new investment was being made to improve old buildings and production solutions which limited the number of possible alternatives. In most cases, markets for increased production, as basic requirement for expansion, had been studied by negotiating with the current customers of the farms.

Compared with main investments in buildings, larger choices of alternatives were available for the planning of details and in-house equipment in buildings as well as for machinery selection.
Difficulties in comparison usually occurred when planning the details which could have been solved in many different ways. Missing information made the comparison between solutions more complicated in many cases. Both equipment suppliers and consultants making the construction drawings often lacked knowledge concerning both the functionality of different detail solutions and how the details match together.

According to both the mail survey and the interviews, determining the need for investment was generally less demanding than acquiring information (Table 1). Farmers valued highly the experience of their main customer (e.g. slaughterhouse, dairy) concerning sizeable investments. Their competence and commitment were an important source of information concerning both the continuity of the business as well as technical matters 


\section{AGRICULTURAL AND FOOD SCIENCE}

Vol. 17 (2008): 18-30.

(Table 3). The experiences of other farmers who had made similar investments were acknowledged as well: “...it is true that the experience I got from other farmers was the most valuable information from outside. Their support and knowledge were most important". Professional magazines as well as the Internet and trade fairs were mentioned, but as less important. Concerning the biggest investments among the farmers interviewed, there was little domestic experience available and similar farms were visited abroad. On one farm, the farm's own prototype building was constructed because ready-made references could not be found.

According to the interviews, suppliers (manufacturers and dealers) were an important source of information in most cases, and many details were known only by them (Table 3$)$. "(Brand $A$ ) was a new brand. It was not on this market with that model, so there was no experience of it available here". Suppliers were sources for essential information, but farmers noticed that they had to be critical when listening to suppliers. In several cases, the information had indeed appeared incomplete or even contradictory: "The (Brand $B$ ) dealer decreased the price every week, and changed the specification in his quotation. It was not easy to find the point of that. It was such a show." In general, farmers pointed out that all information has to be put under careful scrutiny from the individual farmer's own point of view.

The interviews showed that advisory organisations were rarely used as a help in finding solutions for improving production processes, but their services were used to assist in construction, planning and drawings. In applying for EU investment subsidies, profitability and liquidity calculations were required. The Finnish advisory systems have a standardised product ('Likvi') for these calculations (Manninen and Karhula 2006), and this product was used by many of the farmers interviewed. Some found it as a real tool for economic planning, while most felt that it was worthwhile only because it has to be enclosed with the subsidy application: “...I have never looked at the paper since...". Two of the farms had allowed the calculation be updated 'voluntarily', since the economic situations had changed on the farms. Likvi was not used to plan for investment in machinery. Nevertheless, most of the farmers interviewed had done their own profitability calculations prior to the investment.

An investment decision means that one of the options is selected to be implemented. With those farmers interviewed, the main decision was made first (e.g. the main construction of the building) followed by sub-decisions concerning size, fittings and optional equipment. Four of the nine farm managers interviewed made the investment decision alone, five more or less together with their spouses (Table 3). Manager-alone decisions were machinery purchases or other technology updates, while large expansions represented a joint commitment of the farming couple.

As a demanding stage in an investment process, many of the farm managers interviewed mentioned the end of the construction phase when production had to be started based on the new premises. However, in the mail survey, this stage appeared not as highly demanding. Experience at the implementing stage caused some of the farm managers interviewed to state that more time and notice should have been paid to leading forward and supervising the building and deliveries.

Success was not studied separately in the mail survey, but the FADN data gave information about the financial performance of the farms which was in line with the nation-wide profitability decline recorded at that time. The average profitability coefficient (family farm income per sum of the wage and interest claims of the farm family) on Finnish farms was 0.67 in 2000 and 0.48 in 2003 (Puurunen 2005, Niemi and Ahlstedt 2006). In our data, highest turnovers were recorded on farms which invested in animal buildings, but despite the higher mean-size and turnover growth of the group, the profitability figures were, on average, not higher than in the other groups (Table 1). According to the correlation analysis within the group which had invested in other buildings, farm profitability figures increased together with turnover and farm size, but in other groups such correlations were not found. No correlations whatsoever were found between profitability fig- 


\section{AGRICULTURAL AND FOOD SCIENCE}

\section{Mattila, T. et al. Investment processes on farms}

ures and the challenge of the different stages of investment.

The farm managers interviewed were all of one shared opinion that the investment in question was successful, besides some minor details which could have been done better. However, only three of them gave directly an indication of improved profitability. Instead, all had experienced success which was based on a decreased amount and an improved quality of work. On the other hand on three farms, daily operations had shown some poor technical details after using the investment. According to the farm managers, different products or solutions would most probably have worked better in their cases. Only one farmer had a clear opinion that he bought supplies at too high a price, but most of the farmers reported on some delays in their investment projects. The delays concerned occurred with both deliveries and sub-contracted work. Nevertheless, only two of the farmers interviewed considered that in future projects they had to be certain of the timetable by including an overdue penalty clause or similar in the contracts.

According to the interviews, two farms whose recent main investment was a machine found the capacity of the new machine well sufficient, or more likely over-dimensioned. However, they had analysed the options available, and selected the most sensible choice. On the other hand, those who had invested in animal husbandry buildings had accelerated their production fast reaching full capacity. Many of them thought afterwards that even a bigger investment would have been justified: "...if you think of it afterwards, an even bigger [investment] would have been possible. I think almost 50 or 30 per cent more volume would go with the same pain here."

\section{Discussion}

The farmers interviewed who had invested in animal buildings had made construction decisions at an early stage with little comparison. However, they had made a lot of comparisons among details, such as in-house equipment and machinery. Managers had had difficulties in acquiring information because some of the building constructions were new on the market. There was little independent information available which could have lead to the early fixing of a main alternative. Comparison data were acquired foremost from suppliers, via the Internet or directly. In addition, information given by suppliers often suffered from lack of accuracy. Mintzberg et al. (1976) stated in their study that a decision-making enterprise evaluates several alternative solutions only as far as options (and information about them) to solve problems are easily available. However, it could be incorrect to suggest that farmers made decisions too fast, because they collected information over a long period of time and any purchase was influenced by experiments from a previous time (Kool et al. 1997). Industrial buyers were involved in an ongoing search for information as well (Borghini et al. 2006). So, comparison may have been shortened by means of earlier experience.

The farm managers interviewed valued highly the information they got from the experience of other farmers. Also, discussions and consultations with a representative of their main customer (usually a dairy or slaughterhouse) often had a definitive role in the decision-making. Professional magazines were generally an important storehouse of information, and magazines read were usually addressed by name. In other studies, professional magazines were often mentioned as the most common source of information (Timonen 2000, Lunneryd 2003). According to Peltoniemi (2004), the use of the Internet is common in looking for technical data or in product comparison. Already in 2003, approximately $64 \%$ of Finnish farmers had access to the Internet. However, based on German data, Rosskopf and Wagner (2005) reported that farmers still respect professional magazines and an advisory system as the most important sources of information, although the use of the Internet is wide. According to Lunneryd (2003), Swedish farmers found as well the experiences of colleague farmers highly valuable, such as the opinion given by the main customer (e.g. dairy company). In his study, he found the need of personal consultations, obtained e.g. from advisory 


\section{AGRICULTURAL AND FOOD SCIENCE}

Vol. 17 (2008): 18-30.

services, increasing towards bigger decisions, when a discussion with an advisor could clarify ideas and solutions. On the contrary in our study, advisors rarely had an important role in the initial stages of the investment process.

Solutions were selected according to their functionality, or rather according to the farm manager's estimation of functionality. This is in accordance with findings of Lunneryd (2003). Despite several sources of information available, large and unique decisions are at least made based basically on the farmer's own experience and values. Respectively, a group of (non-farming) SME entrepreneurs, studied by Palojärvi (2000), regarded their investment decisions as sufficiently rational.

All farms interviewed made some kind of economic calculation prior to an investment decision, but their role were not binding. Farmers studied by Ohlmer et al. (1998) made rough calculations in their own minds when they planned future actions. However, farmers estimated the value of calculations to be low in the long run, because they felt that the accuracy of the data or their farming situation could became uncertain. Exactly the same statement was given several times in our interviews. This may be one reason behind the preference of qualitative approach. In a recent inquiry study concerning the content and use of profitability and liquidity calculations made by rural advisory centres in Finland (Manninen and Karhula 2006), uncertainty over the initial data and a poor response to changes in the farm's operational environment were noted as weaknesses in these calculations.

According to Foxall (1979) and Jacobsen (1997) in the case of tractor purchasing, the selection was based on the purchaser's own experience which normally was not supported by detailed calculations. Taragola et al. (2001) observed that greenhouse farmers made calculations when building new premises, but not when purchasing machinery. Jacobsen (1997) assumed that farmers may not know thoroughly their machinery costs or of what they consist. This can limit the intensity of looking for alternatives (such as hiring contractor services), leading to unnecessary large machines or motivating a high replacement frequency. Similarities to that survey were found in our study in the two inter- viewed cases about pure machinery purchase, the farm managers had bought generously dimensioned equipment with no previous calculation.

Former research has shown that currently available technology creates a complex environment for farmers including many possibilities from which to benefit, but also creates a lot of uncertainty as well (Ondersteijn et al. 2006). That is why an option including advanced technology solutions will seldom be selected, if the purchaser cannot be sure of good functionality and after-sales support (Hogeveen et al. 2004). Ohlmer et al. (1998) observed that farmers try to minimise technology and other risks in big decisions by gathering information, by carrying out their own practical tests and by putting the novelty into practice step by step, if possible. One or more of these means were used by all interviewed farmers in our study. However, real 'technology leaps', such as implementing a milking robot, could not be prepared by other means than collecting information.

The farmers profiled the success of an investment usually with qualitative measures, of which the level and the quality of work were the most frequently mentioned. Just a few of the farm managers interviewed described the outcome of their investments by means of economic terms. The development of the economic result of the Finnish FADN farms during the last years was demonstrated in our mail survey: profit figures had declined on average despite the kinds of investment having taken place. This is in accordance with the studies of Puurunen (2005). However, the farmers interviewed had gained, at least, a meaningful continuation for their work on the farm, although the profitability factor may not have reached the level expected by far in other kinds of industries.

According to the interviews, farmers were quite satisfied with their investments made and they felt that most of their expectations had been realised. Anyhow, when they looked back at the investment process, they found details which they would have done differently if they had the possibility of doing them again. In a study among 302 Wisconsin dairy producers respectively, only $12 \%$ were not satisfied with their expansion. Slightly more than half $(52 \%)$ of the respondents would have made 
Mattila, T. et al. Investment processes on farms

the expansion faster or bigger, when they evaluated the results afterwards (Bewley et al. 2001). According to Robinson et al. (2002), being proud of his/her farm ownership is one of the most important values of a farmer. State-of-art production facilities and machinery are clearly something of which to be proud. It may be easier for a farmer to give critical comments on details as to his or her main selections which have been made based on strategic decisions.

\section{Conclusion}

In this study, large investments as a complex decision process on farm level was analysed. One result of this study is that decision-making as well as measuring success were widely based on qualitative measures. Although enterprise economics play a key role in all investments, the most profound reason for implementation seemed to be to better life and to improve working conditions in a sustainable way. Investment was a part of planned long-term farm development and, as such, it was presented as a general success story showing only minor problems of detail. This study confirmed that models developed for industrial buying behaviour are valuable tools also for studying farm processes. However, the education level of farmers or their experience was not measured in this study, something which can be considered as a limitation.

Special attention is needed in the first stages of the process: do farm managers really consider all possible alternatives available for their farms, or do they fix the specifications of the solution too early? Another interesting question would be how to find all prospect solutions which could solve the problem and how to find information as to how solutions really perform when fulfilling the needs. It seems to be that farmers as customers do not get, nor do they require, enough clear information from suppliers. By delivering enough adequate information, the supplier should guarantee to get a satisfied customer with long-time supplier loyalty. It should be on scope of future research to fill in the information gap between farm managers and suppliers.

Acknowledgements. The financial support of Maatalouskoneiden tutkimussäätiö (Research Foundation of Finnish Agricultural Machinery) is gratefully acknowledged. The authors also wish to thank the two anonymous referees for their constructive comments.

\section{References}

Anderson, C.D. 1987. The state of knowledge on farmers' buying processes for major farm machinery. School of Management Working Papers 34/87. Cranfield University

Bewley, J., Palmer, R.W. \& Jackson-Smith, D.B. 2001. An Overview of Experiences of Wisconsin Dairy Farmers who Modernized Their Operations. Journal of Dairy Science 84: 717-729.

Borghini, S., Golfetto, F. \& Rinallo, D. 2006. Ongoing search among industrial buyers. Journal of Business Research 59: 1151-1159.

Doyle, D., Jolly, R., Hornbaker, R., Cross, T., King, R.P., Koller, E.F., Lazarus, W.F. \& Yeboah, A. 2000. Case Studies of Farmers' Use of Information Systems. Review of Agricultural Economics 22: 566-585.

Foxall, G.R. 1979. Farmers' Tractor Purchase Decisions: A study of interpersonal Communication in Industrial Buying Behaviour. European Journal of Marketing 13: 299-308.

Hadley, G.L., Harsh, S.B. \& Wolf, C.A. 2002. Managerial and Financial Implications of Major Dairy Farm Expansions in Michigan and Wisconsin. Journal of Dairy Science 85: 2053-2064.

Haring, A.M. 2003. Organic dairy farms in the EU: Production systems, economics and future development. Livestock Production Science 80: 89-97.

Hogeveen, H., Heemskerk, K. \& Mathijs, E. 2004. Motivations of Dutch farmers to invest in automatic milking system or a conventional milking parlour. In: Automatic Milking: A Better Understanding. Wageningen, the Netherlands. 56-61.

Jacobsen, B.H. 1997. Farmers' machinery investments. In: Öhlmer, B. \& D. Lunneryd (eds.). Learning in farmers' decision making. Report No 116, Department of Economics, Swedish University of Agricultural Sciences, Uppsala, Sweden. V:1-10.

Johnston, W.J. \& Lewin, J.E. 1996. Organizational buying behaviour: Toward an integrative framework. Journal of Business Research 35: 1-15.

Kool, M., Meulenberg, M. \& Broens, D. 1997. Extensiveness of Farmers' Buying Processes. Agribusiness 13: 301-318.

Lunneryd, D. 2003. Unique Decision Making with Focus on Information Use The case of converting to organic milk production. Department of Economics, Swedish Univer- 


\section{AGRICULTURAL AND FOOD SCIENCE}

Vol. 17 (2008): 18-30.

sity of Agricultural Sciences. Uppsala, Sweden. 214 p.

Manninen, M. 2004. Työn ja talouden hallinta laajentaneilla lypsykarjatiloilla. Helsinki: MTT Agrifood Research Finland. Selvityksiä 81. 66 p. In Finnish. Abstract: The management of work and economy on growing dairy farms in Finland.

Manninen, M. \& Karhula, T. 2006. Maatalouden taloussuunnittelun ja seurannan tehostaminen. Helsinki: MTT Agrifood Research Finland. Selvityksiä 111.50 p. In Finnish. Abstract: More efficient planning and followship of farm economics.

Micheels, E., Katchova, A. \& Barry, P. 2004. Machinery Investment in Illinois: A Study Examining Existing Investment Motivations. AAEA Annual Meeting, Denver, Colorado. 1-17. Available on the internet: http://agecon. lib.umn.edu/cgi-bin/pdf_view.pl?paperid=14147. Cited 1 March 2007.

Mintzberg, H., Raisinghani, D. \& Théorêt, A. 1976. The Structure of 'Unstructured' Decision Process. Administrative Science Quarterly 21: 246-275.

Niemi, J. Ahlstedt, J. (ed.). 2006. Finnish Agriculture and Rural Industries 2006. Helsinki: MTT Agrifood Research Finland, Economic Research. Publications 106. 94 p.

Ohlmer, B., Olson, K. \& Brehmer, B. 1998. Understanding farmers' decision making processes and improving managerial assistance. Agricultural Economics 18: 273-290.

Ondersteijn, C.J.M., Giesen, G.W.J. \& Huirne, R.B.M. 2006. Perceived environmental uncertainty in Dutch dairy farming: The effect of external farm context on strategic choice. Agricultural Systems 88: 205-226.

Palojärvi, J. 2000. Decision-making of SME entrepreneur: a psycho-social perspective. Rovaniemi: University of Lapland. Acta Universitatis Lapponiensis 29. 365 p.

Peltoniemi, A. 2004. Maatilojen sähköinen liiketoiminta ja verkottuminen. Helsinki: Pellervo Economic Research institute PTT. Pellervon taloudellisen tutkimuslaitoksen työpapereita n:o 69. 55 p. In Finnish.

Puurunen, M. 2005. Comparability of the income concepts according to the agricultural statistics in Finland. In: Poppe, K. (ed.). Microeconomic Data on Farm Diversification, Rural Businesses and Intra-generational Transfer. The Hague, the Netherlands: Agricultural Economics Research Institute (LEI). p. 23-36.

Rantamäki-Lahtinen, L. 2004. Maatilojen monialaistaminen - Empiirinen analyysi monialaisuuteen vaikut- tavista tekijöistä. Maa- ja elintarviketalous 50: 1-131. In Finnish. Abstract: On-farm non-agricultural diversification in Finland.

Robinson, B., Freebairn, D., Bell, K. \& Huda, S. 2002. Surveying farmers' goals and values reveals their diverse motivations and beliefs. Australian Government Grains Research and Development Corporation. Kingston, Australia: Ground Cover 1-5 p. Available on the internet: http://www.apsru.gov.au/apsru/Projects/WFS/achievements/Evaluations.htm. Cited 14 March 2007.

Robinson, P.J., Farris, C.W. \& Wind, Y. 1967. Industrial Buying and Creative Marketing. Boston: Allyn and Bacon.

Rosskopf, K. \& Wagner, P. 2005. Management of Farmers - From Data Generation to Knowledge Sharing. EFITA/ WCCA Joint Congress on IT in Agriculture. Adoption and Extension (1). Vila Real, Portugal. Available on the internet: http://www.efita.net/apps/accesbase/dbsommaire.a $\mathrm{sp} ? \mathrm{~d}=5737 \& \mathrm{t}=0$ \&identobj $=$ sqlwfrJy\&uid $=57305290 \&$ sid $=57305290 \& i d k=1$. Cited 20 December 2006 .

Sipiläinen, T. 1997. Aspects of farmers' decision-making - empirical examples of unique or low frequency decisions. Learning in farmers' decision making. Report No 116, Department of Economics, Swedish University of Agricultural Sciences, Uppsala, Sweden.

Sonkkila, S. 2002. Farmers' decision-making on adjustment into the EU. Helsinki: University of Helsinki, Department of Economics and Management. Publications No. 34. 160 p.

Taragola, N., van Lierde, D. \& van Huylenbroeck, G. 2001. Accounting Data as Aid for Decision Making of Belgian Glasshouse Managers. In: Beers et al. (eds.). PACIOLI 9. The Hague, the Netherlands: Agricultural Economics Research Institute (LEI). p. 131-149.

Timonen, R. 2000. Yrittävyys, liikkeenjohto ja menestyminen maatilayrityksissä. University of Helsinki, Department of Economics and management. Publications 28. 234 p. In Finnish. Abstract: Entrepreneurship, Management and Success in Farm Businesses.

Verville, J. \& Halingten, A. 2003. A six-stage model of the buying process for ERP software. Industrial Marketing Management 32: 585-594.

Wilson, P., Hadley, D. \& Ashby, C., 2001. The influence of management characteristics on the technical efficiency of wheat farmers in eastern England. Agricultural Economics 24: 329-338. 
Mattila, T. et al. Investment processes on farms

\title{
SELOSTUS
}

\section{Investointiprosessin hallinta suomalaisilla maatiloilla}

\author{
Timo Mattila, Marja Manninen ja Pasi Rikkonen, Hanna-Riitta Kymäläinen \\ MTT Taloustutkimus ja Helsingin yliopisto, Agroteknologian laitos
}

Maatalouden rakennemuutos edellyttää tiloilta jatkuvia investointeja tuotantovälineisiin. Tilan talouden ja toiminnan kannalta olisi tärkeää, että nämä investoinnit myös onnistuisivat mahdollisimman hyvin. Tässä tutkimuksessa selvitettiin suomalaisille kirjanpitotiloille tehdyn kysely- ja haastattelututkimuksen avulla investointiprosessin vaiheita ja niiden vaativuutta. Lisäksi kartoitettiin viljelijöiden tiedonhankintatapoja ja heidän käsitystään investointien onnistumisesta. Tutkimuksen mukaan kotieläinrakennukset koettiin investoinneista vaativimmiksi. Investointien suunnittelua pidettiin toteuttamista vaikeampana, ja eri vaihtoehtojen vertailu katsottiin kysytyistä vaiheista kaikkein vaativimmaksi. Viljelijät hankkivat tietoa investointikohteista monin tavoin ennen päätöksentekoa. Varsinkin asiakkaiden näkemykset ja toisten viljelijöiden kokemukset olivat arvostettuja lähteitä. Uudentyyppisistä ratkaisuista ja niiden yksityiskohdista sekä toimivuudesta omalla tilalla oli kuitenkin usein vaikea saada tietoa. Tavarantoimittajien antamaan informaatioon taas tuli viljelijöiden mielestä suhtautua kriittisesti. Päätöksenteon tueksi tehtiin erilaisia laskelmia, mutta laadulliset tekijät olivat siitä huolimatta valinnassa ratkaisevia. Suuret perusratkaisut tehtiin suhteellisen varhain, ja niiden yksityiskohtia hiottiin ja vertailtiin kauan. Viljelijät olivat tekemiinsä investointeihin keskimäärin tyytyväisiä. Tyytyväisyyttä tuottivat viljelijöiden mukaan erityisesti työolojen paraneminen ja työn määrän väheneminen, joten laadulliset tekijät nousivat myös investoinnin onnistumista arvioitaessa taloudellisten tekijöiden rinnalle. 